\title{
Experimental on the Residential Building of Earthquake Prone Areas using Shake Table Test
}

\author{
Neha Tirkey, G.B. Ramesh Kumar
}

\begin{abstract}
This paper highlights the experimental analysis on the Shake Table Test. The Shake Table is an equipment by which real earthquake conditions, forces and vibrations on any structure can be experimented, recorded and studied. When an earthquake occurs over an area it leads to the pause of the normal day to day life, havoc damages, loosing of human lives and failure of the structures. In this study the model is mounted is on the shake table and the vibrations are recorded. The Limit State Design criteria is considered from IS 456:2000 and for Seismic analysis the Load Combination is considered from IS 1893(PART-I):2002.
\end{abstract}

Keywords - EARTHQUAKE, SHAKE TABLE, BASE ISOLATION.

\section{INTRODUCTION}

The earth is made up of four layers. The inner core which is the innermost layer of the earth followed by the above layer known as outer core then mantle region which is semi solid in nature and the crust is the upper most layer where mankind dwells being the thinnest part made up of tectonic plates. There are two types of crust one is oceanic crust which is found below the ocean and the other one is continental crust forms due to the crashing of tectonic plates for an example The Himalayan mountains. The worst and most powerful earthquake happened on 22 May, 1960 the Valdivia earthquake which was 9.6 in magnitude and prolonged for 10 minutes and caused numerous of disaster killing of thousands of people. Earthquakes are natural as well as manmade phenomenon both are devastating in nature. Manmade earthquakes are due to mining activities or nuclear bombing whereas natural disasters cannot be predicted and are caused when two tectonic plates slides over each other or collides over each other. The stored energy within them breaks out and reaches to earth surface through the epicenter in the form of seismic waves causing the ground to shake and leads to destruction. Postearthquake the structure becomes debris and is an important and challenging work for a Civil engineer to rebuild the structure and to design the structures that could minimize the effect of earthquakes for the future disaster. In this paper we will analyze the model considering it as a substitute model of a seismic isolated structure using Shake Table provided at the required intensity.

Revised Manuscript Received on April 12, 2019.

NehaTirkey,M.E. Structural Engineering, Civil DepartementSaveetha School of Engineering, Chennai, T.N, India. (E-mail: Neha.alice22@gmail.com)

Dr. G.B. Ramesh Kumar, M.E.,Ph.D, 2Associate Professor of Structural EngineeringSaveetha School of Engineering, Chennai, T.N, India. (E-mail: rameshkumargb@gmail.com)

\section{SHAKE TABLE}

The first shake table was invented in Japan in the year1890, they mounted the model on a surface which was attached with wheels and was experimented on the rail track. In Japan it is widely used and the importance of the Shake Table is that it is being used in present era to stimulate the earthquake response. The model here is subjected to same response as that of the earthquake, the vibrations on the model is generated in $\mathrm{X}$ and $\mathrm{Y}$ directions and the readings are recorded and manually calculated. The experiment can be performed on heavy structures as well as on small model depending upon the type the Shake Table can be used. Mainly there are three types of Shake Table Uniaxial, Biaxial and Multiaxial depending of the experimental analysis it is used.

\section{A. Uniaxial Shake Table}

The Uniaxial Shake Table is used for small scale experiments to observe the response of the structure when subjected to earthquake vibration. It is used as a base plate where the model is shaken and driven by electronic servo actuators and record data of the displacement of the structure. The table size varies from $0.5 \mathrm{~m} \mathrm{X} 0.5 \mathrm{~m}, 1 \mathrm{~m} \mathrm{X}$ $1 \mathrm{~m}, 1.5 \mathrm{~m} \mathrm{X} 1.5 \mathrm{~m}, 2 \mathrm{~m}$ X $2 \mathrm{~m}$. The withstanding capacity of table frequency is more than $100 \mathrm{~Hz}$ and the load capacity is up to $50-10000 \mathrm{~kg}$. The system consist of digital control and data acquisition to connect various transducers. It is user friendly with easy installation, it does not require any skilled professional.

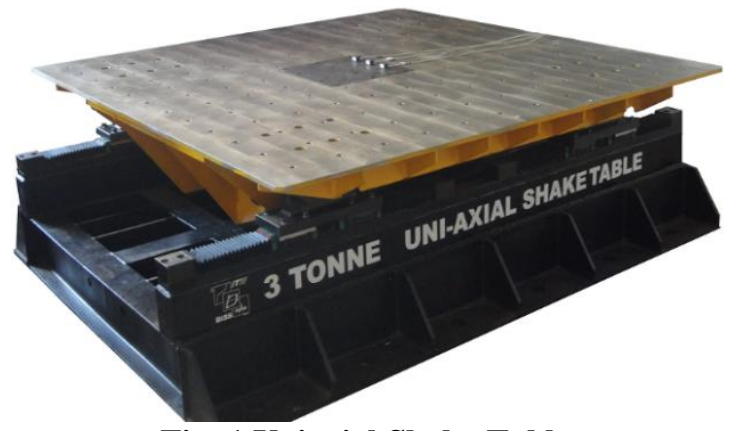

Fig. 1 Uniaxial Shake Table

\section{B. Biaxial Shake Table}

The Biaxial Shake Table is also works on the same principle as that of Uniaxial Shake Table recording the 
seismic activity of the structure but it is a better option if we compare with the Uniaxial Shake Table because here the table provides movement in both $\mathrm{X}$ and $\mathrm{Y}$ direction. The table sizes varies from $0.5 \mathrm{~m} \times 0.5 \mathrm{~m}, 1 \mathrm{~m} \mathrm{X} 1 \mathrm{~m}, 1.5 \mathrm{~m} \mathrm{X}$ $1.5 \mathrm{~m}, 2 \mathrm{~m} \times 2 \mathrm{~m}, 3 \mathrm{~m} \mathrm{X} 3 \mathrm{~m}$. It is driven by hydraulic actuators having load carrying capacity of 50-10000 kg and withstanding frequency of more than $100 \mathrm{~Hz}$. It is also easy to install and user friendly. It is designed for carrying high intensity load and frequency. By the help of hydraulic actuators the movement in $\mathrm{X} \& \mathrm{Y}$ directions are controlled. The experiments can be conducted in labs using this table.

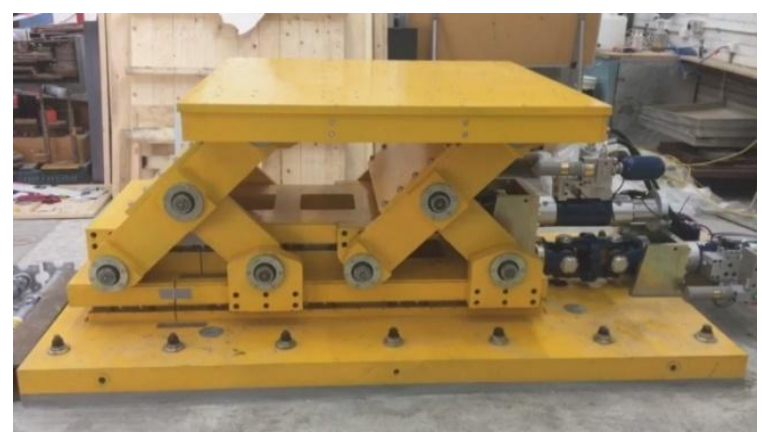

Fig. 2.Biaxial Shake Table

\section{Multiaxial Shake Table}

With the Multiaxial Shake Table real time earthquake seismic activities can be experimented on the modular structure. It provides six axis of motion and is appropriate for usage as it uses large number of digital acquisition to record the seismic activities, displacement and frequency. This Table can be utilized for large structures in a laboratory under controlled supervisions. The size of the table is $5^{\prime} \mathrm{X}$ 7 ' and the frequency varies from $0.01-50 \mathrm{~Hz}$, the displacement varies up to $250 \mathrm{~mm}$. It is also hydraulic driven actuators, requires less maintenance and easy installation.

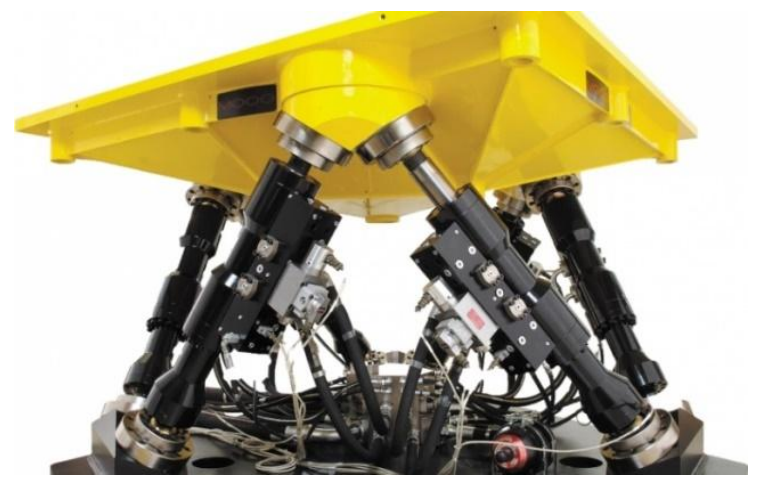

Fig. 3.Multiaxial Shake Table

\section{LITERATURE REVIEW}

A.N Swami Nathen, P. Sankari did Experimental Analysis on the Earthquake Shake Table using GC Schierle Shake Table. The wooden plate was used as a base plate of size $1.5 \mathrm{ft}$ X $1.5 \mathrm{ft}$ attached with springs at all the four corners and the model was mounted over it. The Shake Table is attached with volcano meter and sensor to analyze the vibrations. The seismic activity is recorded by the digitizer and the number of vibrations, acceleration and frequency was noted. Two comparison of the model was made with low and high frequency on the Shake Table. The Linear Variable Transformer (LVDT) is used for measuring displacement of the model. The test concluded that the Shake table is one of the ways by which seismic analysis can be carried out and at high frequency the model showed displacement of $11 \mathrm{~mm}$ at $0.114 \mathrm{sec}$ whereas at low frequency the displacement was $10.4 \mathrm{~mm}$ at $1.45 \mathrm{~Hz}$. It also concluded that Shake table can run on Sine waves and By Wave forms.

Engr. AsifShahzad, Dr. Naveed Ahmad did Experiment on two Storey frame structure model. The model was kept on the Shake Table and artificial seismic waves were generated. The movement of the building was recorded at various time intervals and the result concluded that high strength concrete should be provided with joints. The model was able to resist $70 \%$ of the vibration. The experiment was done on the reinforced concrete structures of low strength concrete and due to the low strength concrete the structure resembled cracks during the test and ultimately model collapsed when frequency of the shake table was increased. The research study was done based on Building Code of Pakistan, BCP-2007.

A.P. Kulkarni, M.K. Sawant, M.S. Shindepatil concluded that seismic dampers are good in absorbing shocks generated during earthquake. The risk of disaster becomes less when compared to structures without base isolation hence base isolation methods are boons to the structure. The experiment is done using Horizontal Shake Table of size $700 \mathrm{~mm} \mathrm{X} 600 \mathrm{~mm}$ and payload is of $5-6 \mathrm{~kg}$ and frequency of $1-10 \mathrm{~Hz}$. Two models of $\mathrm{G}+4$ were experimented with dampers and without dampers at the same time period of 30sec. Both the building showed deflection in $\mathrm{X}$ and $\mathrm{Y}$ direction but deflection in building without dampers was more prone to earthquake and model with dampers showed less deflection. Hence dampers can be used as a shock absorber in the building floors to resist the earthquake vibration and safeguard the structure.

M. Tondelli, S. Petry, S. Peloso, K Beyer concluded in their experiment that unreinforced masonry buildings fails to undertake the seismic load, the cracks were visible and at the end building collapsed whereas the mixed design of unreinforced walls with reinforced concrete walls showed better performance and was able to undergo the seismic load. In countries like Switzerland reinforced masonry walls with unreinforced masonry buildings are adopted as a mixed design to construct the residential buildings. The Shake Table experiment was performed at the TREES laboratory of the European Center for Training and Research in Earthquake Engineering, Italy.

\section{SEISMIC ZONES OF INDIA}

The Indian subcontinent has a history of devastating earthquakes and the major reason for the high frequency and intensity of the earthquakes in the Indian plate. The geographical statics of India shows almost $50 \%$ of land is vulnerable to earthquake. The latest version of seismic zone in map of India is divided into four zones (Zone II,III,IV,V) where Zone $\mathrm{V}$ expect highest level of seismicity whereas Zone II is associated with lowest level of seismicity.

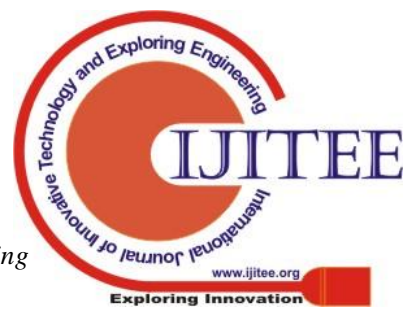


Zone IV

This zone is called high damage risk zone covering area liable to MSK VIII. The IS Code 1893(Part-I):2002 assign factor of 0.24 area mentioned.

Zone $\mathrm{V}$

This zone covers the highest risk zone which suffers earthquake intensity of MSK IX or greater. According to IS Code 1893(Part-A):2002 the area factor is 0.36 .

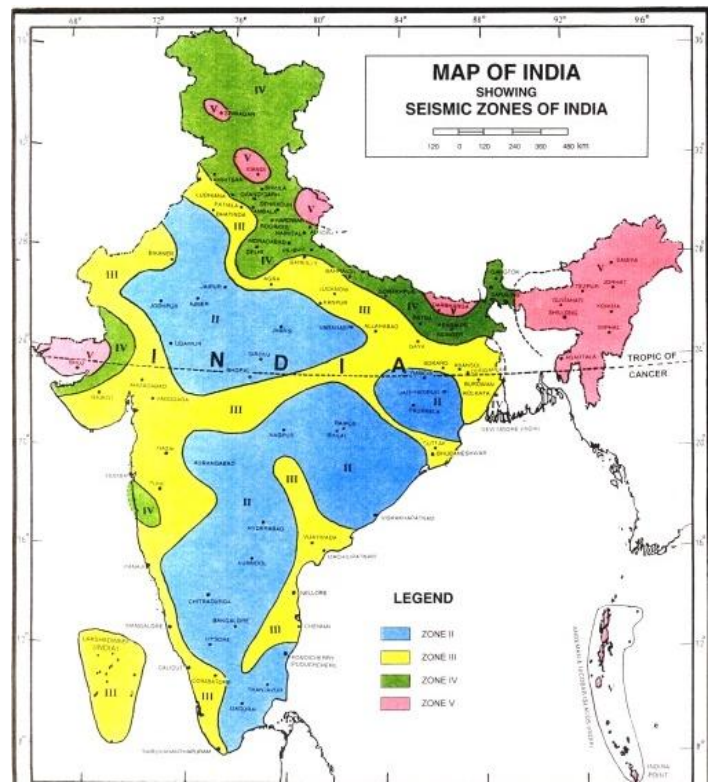

Fig. 4. This map shows the Earthquake zones of India

\section{BASE ISOLATORS}

The first base isolation technique was used in the year 1976 by the Earthquake Engineering Research Centre in the United States. Basically the base isolation method is one of the ways by which seismic activities can be minimised and various types of base isolation systems are available. In the base isolation technique the building is attached with rollers, sliders, rubber plates or led rubber bearings to absorb the energy. The structure with fixed base is more prone to the earthquake when compared to the building with base isolators. The mechanism of base isolators is to absorb shock waves generated during the earthquake. The bearings are provided at the base of the structure between the superstructure and the foundation. During the earthquake the bearings decouples the structure and the vibrations are absorbed by the rubber bearings and the building even though shakes but the risk of collapsing of the building is avoided and the human lives are also saved. On 26 January, 2001 an earthquake of magnitude 6.9 hit Gujarat in India which killed almost thousands of lives and it is one of the major active faults. All the major structural buildings were collapsed and there was a wide gap in the ground which stretched for long and reconstructing the whole Bhuj city was a difficult work. The Bhuji Hospital, Gujarat is an example of Base Isolation System and is the first structure to be used in India.

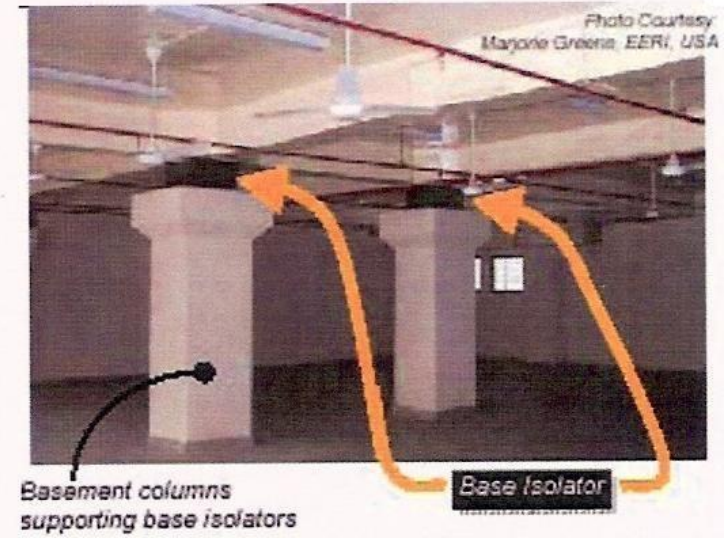

Fig. 5. Base Isolation technique used in Bhuj Hospital, Gujrat

\section{LOAD-BEARING VALUE OF SOIL}

Load bearing is the soil withstanding strength for the load when applied on it. According to IRC (International Residential Code) each soil has its own properties, load carrying capacity depends on the type of soil.

TABLE I. LOAD BEARING VALUE OF SOIL

\begin{tabular}{|l|l|}
\hline Type of soil & LBV Per square foot \\
\hline Bedrock & 12000 \\
\hline Sedimentary Rock & 4000 \\
\hline Sandy Gravel & 3000 \\
\hline Sand, Silty sand, Clayey sand & 2000 \\
\hline Clay, Sandy clay, Silty clay & 1500 \\
\hline
\end{tabular}

\section{RESULTS \& DISCUSSIONS}

The model was designed according to the specified data given in code book for the Limit State of Design. The load combination and the seismic load from the code book IS 1893(PART-I)2002 is taken. The Uniaxial Shake Table is used for the experiment and for the model $\mathrm{G}+2$ is considered.

\section{A. MODEL DIMENSION:}

\begin{tabular}{|l|l|}
\hline Bean Size & $300 \mathrm{~mm}$ X $300 \mathrm{~mm}$ \\
\hline Column Size & $300 \mathrm{~mm}$ X 300mm \\
\hline Floor Height & $3 \mathrm{~m}$ \\
\hline Live Load & $3 \mathrm{KN} / \mathrm{m}^{2}$ \\
\hline Floor Finish & $1 \mathrm{KN} / \mathrm{m}^{2}$ \\
\hline Wall Load & $16.2 \mathrm{KN} / \mathrm{m}^{2}$ \\
\hline Parapet Load & $1 \mathrm{KN} / \mathrm{m}$ \\
\hline Zone Factor & 0.16 \\
\hline Soil Type & Medium \\
\hline
\end{tabular}




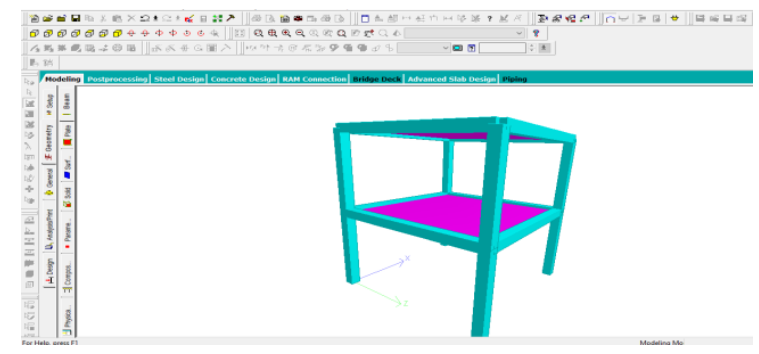

\section{B. LOAD COMBINATION:}

According to the IS 1893(PART 1):2002, the load combinations are considered:

$1.5(\mathrm{DL}+\mathrm{LL})$

1.2(DL+LL+EL)

1.5(DL+EL)

$0.9 \mathrm{DL}+1.5 \mathrm{EL}$

\section{RESULT:}

Accelerometers is a kind of transducers is used here to control the shake table and to observe the response of the structure. The table represents the lateral displacement of the model with base isolation and without base isolation at a certain time.

TABLE II. MODEL DISPLACEMENT WITH BASE ISOLATION

\begin{tabular}{|l|l|l|l|}
\hline \multirow{2}{*}{ Storey } & \multicolumn{2}{|l|}{$\begin{array}{l}\text { Lateral } \\
\text { Displacement(mm) }\end{array}$} & \multirow{2}{*}{$\begin{array}{l}\text { Frequency } \\
\text { (Hz) }\end{array}$} \\
\cline { 2 - 3 } & X & Y & \\
\hline First Floor & 12.6 & 6.7 & 2 \\
\hline Second Floor & 15.3 & 10.4 & 2 \\
\hline
\end{tabular}

The table represents the lateral displacement of the building in $\mathrm{X}$ and $\mathrm{Y}$ direction with the Base Isolation.

TABLE III. MODEL DISPLACEMENT WITHOUT BASE ISOLATION

\begin{tabular}{|l|l|l|l|}
\hline \multirow{2}{*}{ Storey } & \multirow{2}{*}{$\begin{array}{l}\text { Frequency } \\
(\mathbf{H z})\end{array}$} & \multicolumn{2}{|l|}{$\begin{array}{l}\text { Lateral } \\
\text { Displacement(mm) }\end{array}$} \\
\cline { 3 - 4 } & & X & Y \\
\hline First Floor & 2 & 16 & 10.2 \\
\hline Second Floor & 2 & 17.1 & 11 \\
\hline
\end{tabular}

The table shows the lateral displacement of the model in $\mathrm{X}$ and $\mathrm{Y}$ direction without the Base Isolation.

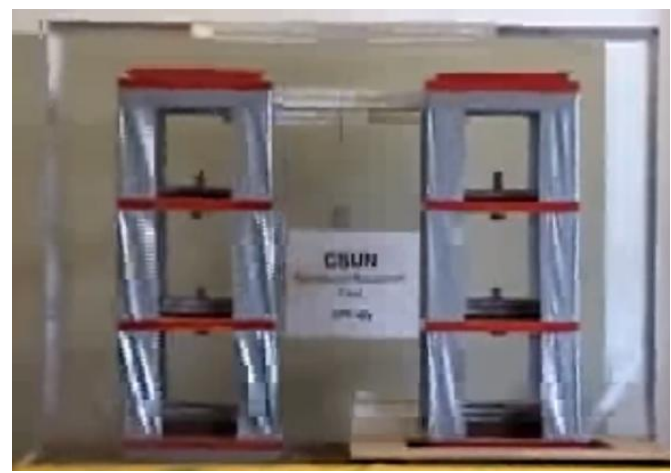

In this experiment the vertical load compared to horizontal load is less because the model consist of two floors and in case of tall building which holds swimming pool or heavy water tanks at the top floor there is a possibility of vertical load will be more because all the load will be transferred to the bottom floors.

\section{CONCLUSION:}

The experimented was conducted successfully inside the college campus and the experiment was only conducted for the study purpose. The experiment concluded that base isolation is an effective way to ensure the safeguard of the building from the earthquake and the flexible pads can be made of lead, steel or rubber. The Shake Table is a method of experiment by which seismic vibrations can be analyzed and studied for experimental purposes. There are various dampers like viscous, vibrational, oil which can be used to absorb the seismic waves. Shear walls, moment resisting frames, diaphragms and cross braces also can be used to resist earthquake movements. Wood is also a substitute being flexible and ductile in nature and easily available can be used. Depending upon the region and type of soil the construction should be done. In hilly regions the slope should be considered and the region where the soil is less in strength pile foundation must be adopted. Light weight material must be used in earthquake prone areas and the height should be kept less.

\section{ACKNOWLEDGEMENT:}

I am thankful to my guide DR. G. B. Ramesh Kumar for his guidance in making the project and thankful to the Civil Department faculty for their cooperation. Lastly, I am thankful to all the people who helped me directly and indirectly for completing my project work.

\section{REFERENCE:}

1. A. N. Swami Nathan, P Sankari "Experimental Analysis of Earthquake Shake Table" published in AJER journal.

2. A. P. Kulkarni, M.K. Sawant, M.S. Shindepatil "Experimental Study Using Earthquake Shake Table" published in IRJET journal.

3. Carlos E, Ventura and Mehdi H. K. Kharrazi "Performance of OFC'S in Earthquake by Shake Table Tests" published in 13WCEE.

4. Engr. AsifShahzad, Dr. Naveed Ahmad "Shake Table Tests on Reinforced Concrete Structure"

5. H. Eramma, Pulakeshi H L "Seismic Performance Evaluation of RC Building Connected with and without X-Braced Friction Dampers" published in IJRET journal.

6. IS 456:2000, Plain and Reinforced Concrete Code of Practice, Bureau of Indian Standard, New Delhi.

7. IS 1893(PART-I) 2002, Criteria for Earthquake Resistant Design of Structures, Bureau of Indian Standard, New Delhi.

8. IS 875(PART-I, II, III) 1987, Code of Practice for Design Loads for Building and Structures, Bureau of Indian Standard, New Delhi.

9. M. Tondelli, S Petry, S Peloso, K Beyer "Shake Table Test on a Four-Storey Structure with Reinforced Concrete and Unreinforced Masonry Walls

10. N. Nakashima, K. Kawashima, H Ukon and K. Kajiwara "Shake Table Experimental Project on the Seismic Performance of Bridges using E Defense.

11. Rakesh D.R, Kavitha S.T, Felix Kala "Comparative Study on Seismic Performance of Bamboo and Steel using Shake Table published in IJITEE journal.

12. R. T. Severn and D.P. Stolen, Y. Tagawa "The Contribution of Shaking Tables to Eathquake Engineering" published in 15WCEE. 